\title{
Second-Life Batteries on a Gas Turbine Power Plant to Provide Area Regulation Services
}

\author{
Lluc Canals Casals * and Beatriz Amante García \\ Department of Project and Construction Engineering, Universitat Politècnica de Catalunya, \\ 08222 Terrassa, Spain; beatriz.amante@upc.edu \\ * Correspondence: 1luc.canalsl@upc.edu; Tel.: +34-93-7398-154
}

Academic Editor: Maciej Swierczynski

Received: 30 September 2016; Accepted: 14 March 2017; Published: 17 March 2017

\begin{abstract}
Batteries are used in the electricity grid to provide ancillary services. Area regulation seems to provide substantial revenues and profit, but $\mathrm{Li}$-ion batteries are still too expensive to enter widely into this market. On the other hand, electric vehicle (EV) batteries are considered inappropriate for traction purposes when they reach a state of health $(\mathrm{SoH})$ of $80 \%$. The reuse of these batteries offers affordable batteries for second-life stationary applications. This study analyzes two possible scenarios where batteries may give power and energy support to a gas turbine cogeneration power plant, and how long these batteries may last under different loads.
\end{abstract}

Keywords: aging model; lithium-ion batteries; second life applications; area regulation

\section{Introduction}

The entrance of the electric vehicle (EV), the growth in industry, and world energy demand together, with a raise in environmental consciousness, force the transformation of the electricity grid in many countries. New electricity services are under study for their expected economic or functional benefits such as: peak shaving, load leveling, area regulation, transmission deferral, renewable firming, among others [1-4], in addition to new concepts, like distributed generation [5] or the need for smart grid implementation [6]. Energy storage systems (ESS) offer solutions to these new businesses [7], but their possible entrance to the electricity market depends of the particularities of each country. For example, the important penetration of wind and solar energy generation and the high-energy and ancillary services prices in Spain are highly attractive factors. On the contrary, its major drawback resides in the lack of subsidies and impeding regulation [8].

Nonetheless, batteries seem to be able to provide optimal responses for many of these services. In particular, lithium-ion batteries are the ones having a wider range of applications [9]. However, although lithium-ion batteries' prices are expected to decrease in the following years, they are still too expensive to be massively deployed on stationary applications [10].

To overcome this economic barrier, the idea to reuse batteries from electric vehicles has been proposed. It is generally accepted that EV batteries are expected to be inappropriate for traction purposes after they reach an $80 \%$ of their state of health $(\mathrm{SoH})$ [11]. Still having a significant amount of functional capacity, Foster et al. [12] consider that $85 \%$ of all EV batteries may be reused on the aforementioned stationary applications at a much lower cost [13], giving them a second life and possibly leading to a cost reduction of EV prices [14]. In fact, different ways to affront remanufacturing processes have been already proposed, such as direct reuse [15,16] or module and cell dismantling [17].

Second-life batteries in electricity grid quality services find an important market with profitable businesses. In fact, area or frequency regulation-which increases or decreases the energy injected into the grid to instantly balance generation and demand, or maintain the frequency between the working limits—seems to be the most promising $[18,19]$. 
Nowadays, area and frequency regulation services are provided by turbine generators due to their relatively fast response in comparison to other mechanic systems. Moreover, hydraulic turbines generally provide this service due to their low operation cost, as they have no need to buy and burn any fuel. However, season and weather conditions may disrupt their functionality, giving gas turbines and other cogeneration plants the opportunity to participate into the business. Trying to increase their participation in the electricity regulation market, gas turbines may profit from second-life batteries to gain competitiveness. This study presents two study cases where second-life batteries give support to a gas turbine power plant and estimates their rest-of-useful life (RUL) under these two scenarios.

In order to precisely estimate RUL, it is necessary to use an aging model that considers all factors that have an influence on battery aging. Devie and Dubarry [20] reported that most studies use inaccurate aging models. In fact, many use simple models based on the expected number of cycles; the accumulated ampere hour (Ah) throughput; or expected lifetime, adjusted by temperature, Depth of Discharge $(D o D)$ [19], or, in the best cases, adjusted by more than one factor. The aging model used in this paper considers calendar and cycling aging adjusted by the following factors: State of Charge $(\mathrm{SoC})$ or voltage $(V), D o D$, current or intensity (C-rate), temperature $(T)$, Ah throughput, and time $(t)$ [21].

In summary, this study estimates the RUL of a second-life EV battery applied to real area regulation signals by means of an equivalent electric circuit model. To do so, this study considers a directly reused $24 \mathrm{kWh}$ battery from a single EV installed on a $500 \mathrm{~kW}$ up/down power plant built on multiple gas turbines, specifically dedicated to area regulation services under two possible work scenarios.

The paper is structured as follows: first, primary results are shown, followed by a Discussion section. Next, the Material and Methods section presents the details of the scenarios and the battery aging model used in order to fully understand the results presented beforehand. Finally, a Conclusion section summarizes the study and highlights major findings.

\section{Results}

In the first scenario, turbines work under a softened load resulting from the average demand of set points during the previous minute. Figure 1 presents the resulting working loads for gas turbines (orange) and batteries (black), which together follow the set points (blue) given by the electricity grid operator. The total amount of energy exchanged by the battery during this $1 \mathrm{~h}$ period is close to $22.38 \mathrm{kWh}$, considering charge and discharge together.

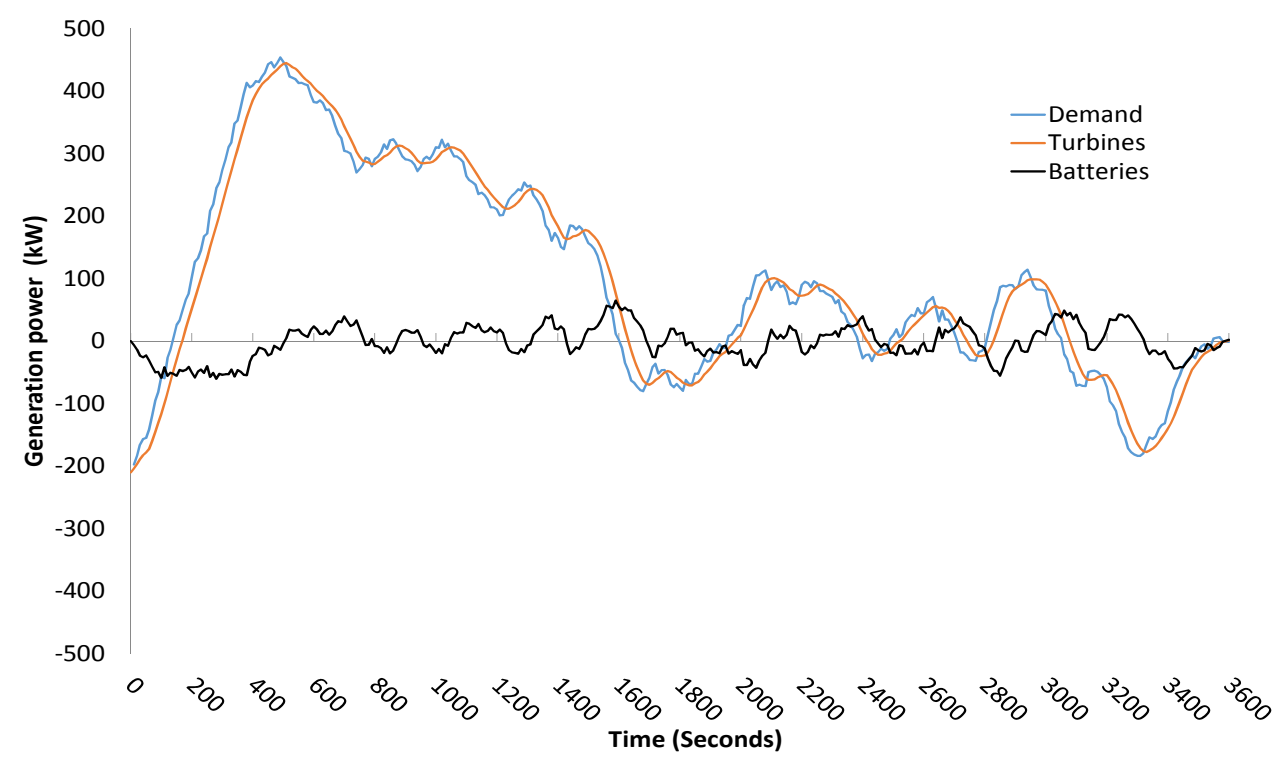

Figure 1. Working load of turbines and batteries in contrast to demand for the first scenario. 
On the other hand, Figure 2 presents the working loads for turbines (grey) and batteries (black) resulting from the second scenario, where turbines work under constant power or constant acceleration/deceleration states.

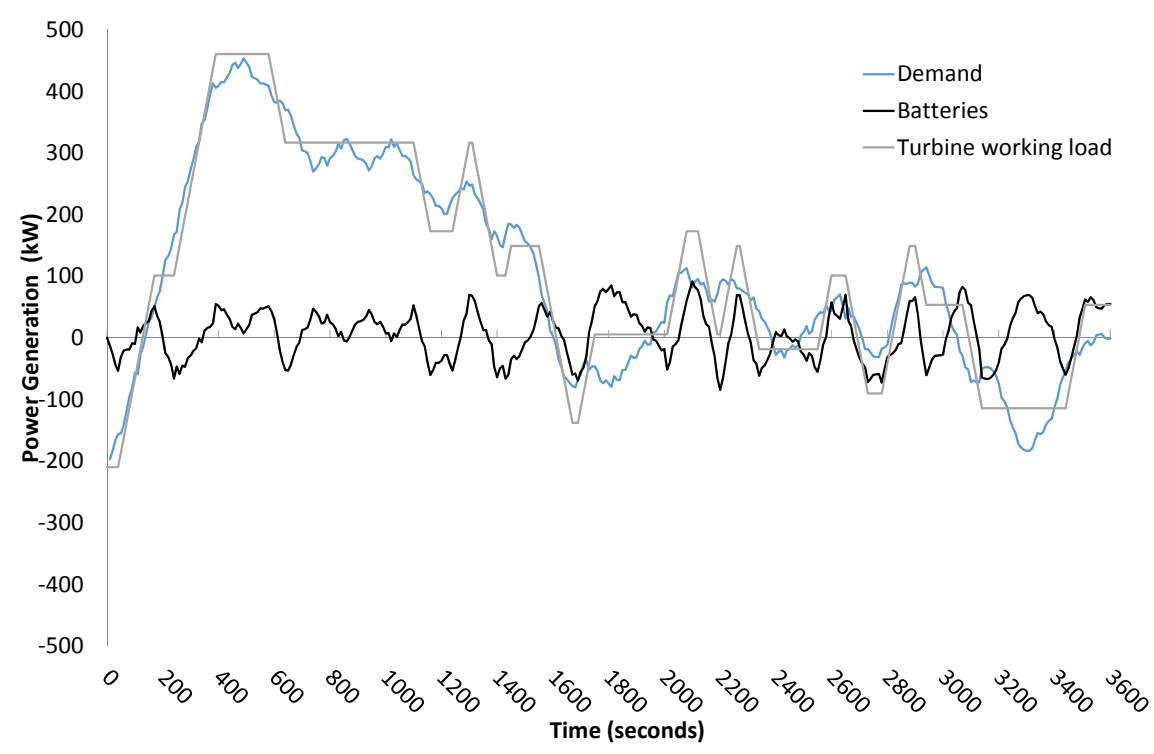

Figure 2. Working load of turbines and batteries in contrast to demand for the second scenario.

Notice that the energy exchanged by the battery in this second scenario raises above $40 \mathrm{kWh}$ (20 kWh charge/discharge), which almost doubles the amount of energy exchanged in scenario 1. Additionally, this scenario requires higher power rates to the battery than the first scenario.

Considering the extreme load conditions, 24 and 22 continuous cycles per day in the first and second scenario, respectively, it is not surprising that batteries age quickly. Figure 3 shows the aging or SoH evolution against the number of cycles for the first scenario. These results indicate that the EV battery-installed to provide softer working changes to turbines-lasts over 2000 cycles before reaching its end of life (EoL). The EoL occurs when the battery cannot provide all the energy needed to fulfill the demand set points given by the electricity regulator. That is, the battery reaches its minimum SoC conditions while the systems still demand energy. This EoL corresponds to a $46.53 \% \mathrm{SoH}$ (Figure 3 ) and it is reached after 84 days working nonstop, which represent a total amount of energy drawn from the battery of $22,293 \mathrm{kWh}$.

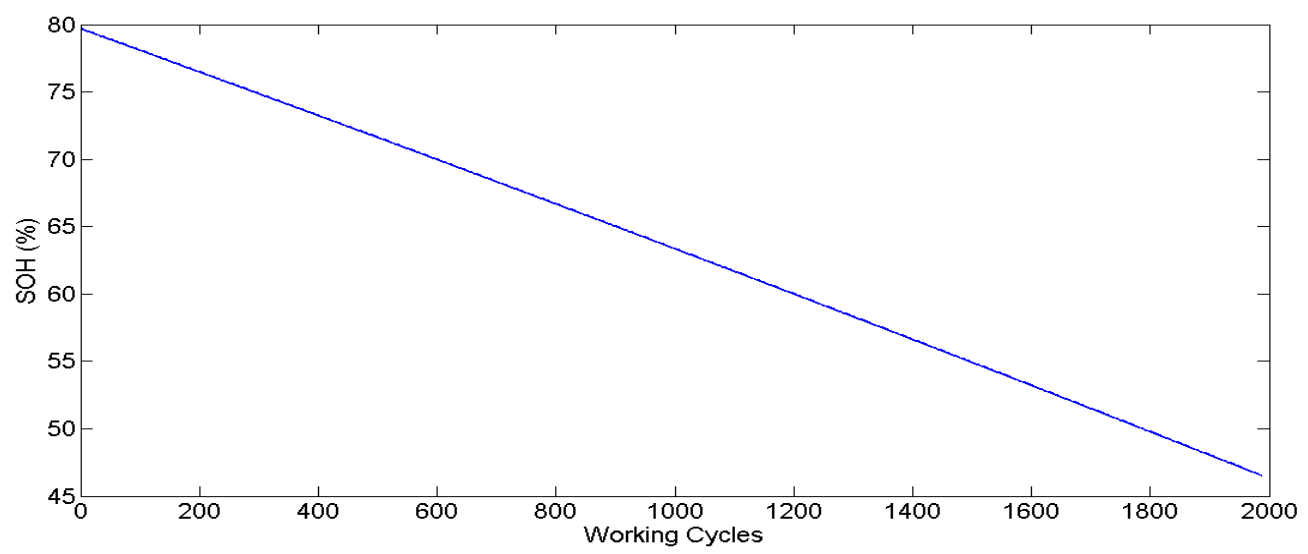

Figure 3. Aging evolution of second-life electric vehicle (EV) batteries under the $1 \mathrm{~min}$ time lag. 
Figure 4 presents the evolution of SoC (black) according to the input current load (red) in one of the last cycles of the battery for the first scenario. Notice that minimum SoC is close to $10 \%$ and maximum SoC is near 95\%, while at the beginning of the second life, SoC ranged from $95 \%$ to $40 \%$. In fact, $95 \%$ and $10 \%$ SoC are some working limitations fixed by the car manufacturer to ensure battery lifespan during its first life. These limitations cannot be modified for the second life if we expect car manufacturers to maintain the warranty during the second life.

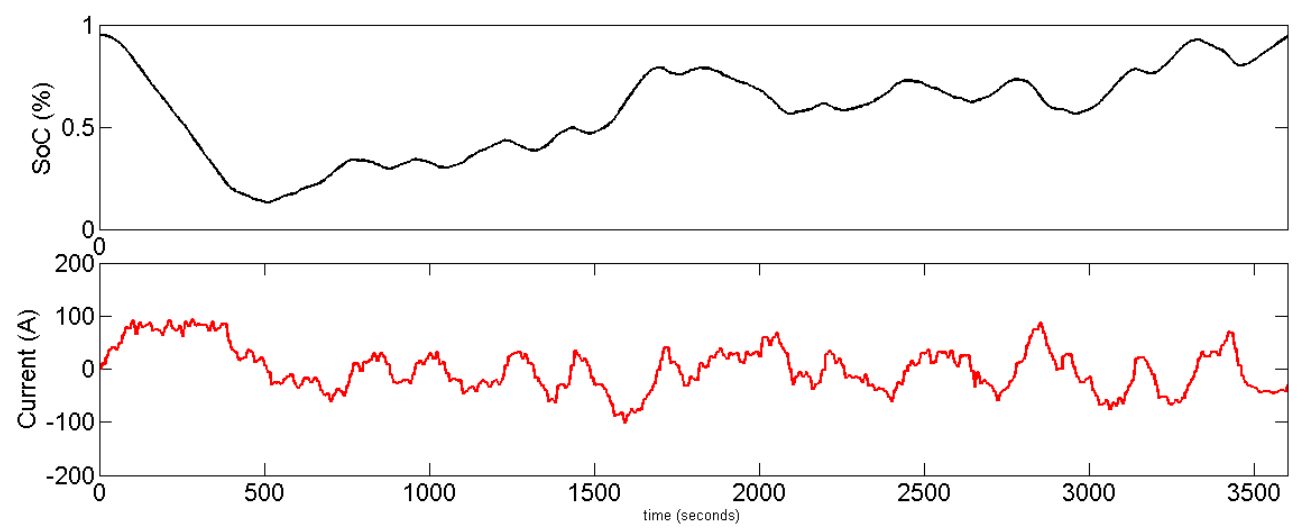

Figure 4. Battery state of charge (SoC) evolution (up) in one of the last simulated cycles following the first scenario input current (down).

Finally, Figure 5 presents the evolution of SoH (or aging) for the second scenario. Having higher power and energy demand than the battery, the EoL in this scenario corresponds to $51.43 \% \mathrm{SoH}$, which is a $5 \%$ higher than in the first scenario. Moreover, Figure 5 shows that it takes less than 800 cycles to reach this EoL, which correspond to only 36 days and a total amount of energy drawn by the battery of $15,919 \mathrm{kWh}$. This means that, under the second scenario, the battery's lifespan is less than half the lifespan of the first scenario.

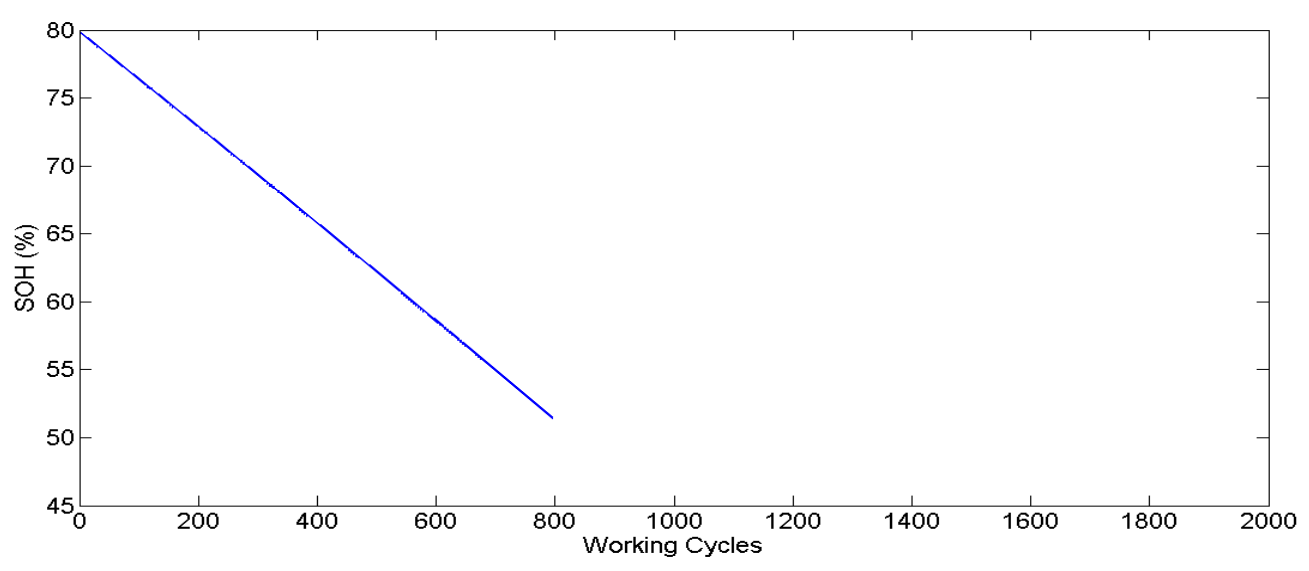

Figure 5. Aging evolution of second-life EV batteries following the second scenario load.

A comparison between Figures 3 and 5 is enough to appreciate how higher load requirements have a strong impact on battery aging.

Knowing that, for security reasons and to enlarge lifespan, the EV battery capacity range is limited to a $95 \%-10 \%$ SoC range and that the EV battery has $24 \mathrm{kWh}$ capacity when fresh, its available capacity is reduced to $20.4 \mathrm{kWh}$ at the beginning of the first life. In addition, if the second life begins at $80 \%$ $\mathrm{SoH}$, the available capacity at the beginning of the second life is reduced to $16.32 \mathrm{kWh}$. Finally, at the EoL of scenario 1 and 2, the battery capacity decreases until 9.49 and $10.49 \mathrm{kWh}$, respectively. 
Lifespan results are expressed in working cycles, which are different for both scenarios. Thus, in order to compare result, they should be translated to full equivalent cycles. A full equivalent cycle is a complete discharge and charge cycle, from $100 \% \mathrm{SoC}$ to $0 \%$ and back to $100 \% \mathrm{SoC}$. In our case, as the battery degrades over time, the capacity of a full equivalent cycle also declines. In consequence, the battery does 0.69 equivalent full cycles per working cycle at the beginning of the second life for the first scenario, which corresponds to 16.45 equivalent full cycles per day, and ends up doing 1.18 equivalent full cycles per working hour at the EoL (when the battery has only $9.49 \mathrm{kWh}$ capacity), corresponding to 28.3 equivalent full cycles per day. This means that, during the whole lifespan, the battery performs 1880 equivalent full cycles.

Similarly, the second scenario has a ratio between equivalent full cycles and working cycles of 1.23 at the beginning of the second life and 1.91 when the battery reaches the EoL. This represents the battery performing 29 equivalent full cycles per day at the beginning of the second life, and ends up doing 42 equivalent full cycles, which corresponds to a lifespan of 1241 equivalent full cycles. This is still lower than in scenario 1 , but $1 / 3$ higher in comparison to working cycles.

Finally, the difference in aging per cell should be considered. In fact, although using the same type of cells, not all of them will age in exactly in the same manner. Some age slightly faster or slower than others. Most of the aging studies in literature use commercial 18650-format Li-ion cells, which have a relevant deviation regarding aging [22]. However, EV batteries use improved cells with temperature and balancing control devices that reduce this deviation. In fact, a study of cell aging in an EV [23] reported that the deviation observed between all cells when they reached $80 \% \mathrm{SoH}$ corresponded to only $3 \%$. Assuming that aging deviation increases linearly, when they reach the EoL in the analyzed scenarios ( $51 \%$ and $46 \% \mathrm{SoH})$, the deviation would be close to $7.35 \%$ and $8.1 \%$, respectively. This variation means that the EoL may occur within the $51 \% \pm 3.675 \%$ and $46 \% \pm 4.05 \%$ confidence range.

\section{Discussion}

Based on the results presented in Section 2, it seems that battery aging is almost 2.5 times more aggressive when working in the second scenario, which does 800 cycles during 36 days in comparison to the almost 2000 cycles and 84 days in the first scenario. However, this huge difference is blurred by several aspects, such as the working cycle differences and the EoL variation. When comparing results using full equivalent life cycles, their endurance translates to 1880 and 1241 full equivalent cycles for the first and second scenario, respectively. This represents a $6 \%$ reduction for the first scenario and a $56 \%$ increase in the second study case.

Finally, in order to correctly evaluate the aggressiveness of the working loads on battery aging, it is necessary to compare the equivalent full cycles considering the same EoL. To do so, the final SoH will be that of the second scenario, which has a higher value. With this correction, the number of full equivalent cycles performed to reach the $51.43 \% \mathrm{SoH}$ of the battery in the first scenario is reduced to 1508. Thereby, after these corrections, results show that the aging aggressiveness of the second scenario is just $21 \%$ stronger than the aging from the first scenario.

These results do not seem bad when regarding the number of cycles these batteries can do in comparison to the 1000 cycles reported by Ciccioni et al. [24], the 1500 cycles on ancillary services from Strickland et al. [25], or between 2000 and 1000 full equivalent cycles reported by Muenzel et al. [26] on batteries working in the range from $40 \%$ to $100 \%$ DoD, but they are alarming in terms of days. If batteries should work continuously under exposed load conditions, they will certainly not enter into the market.

However, as expressed in the Methodology section regarding the study limitations, a nonstop continuous working condition is rare for gas turbine plants in the area regulation market. Thus, if the number of cycles per day reduces significantly, battery lifespan will increase accordingly.

Furthermore, notice that the EoL estimated for these two second-life applications fall below the $60 \% \mathrm{SoH}$. There are not many studies on EV cells and batteries that cycle batteries until such a low 
$\mathrm{SoH}$. In fact, most of them finish when the battery reaches the $80 \% \mathrm{SoH}$. Therefore, it is possible that other unexpected circumstances will occur beyond this limit, such as the aging knee phenomena.

Nonetheless, the battery control system, being part of the EV battery pack, ensures that the working conditions of the battery will always be under the safety and secure working limits. That is, there would be no overvoltage, overcharge, over-discharge, or overheating, among others. In fact, if the battery management system (BMS) reports to the power plant that the battery is close to any of its working limits, the system would gradually decrease the battery load demand so that it is only able to work with the gas turbine on its current configuration until the battery is checked, replaced, or ready to work again. Figure 6 presents a simplified control diagram that exemplifies how the plant should always work properly, even if there is a failure on the battery stack.

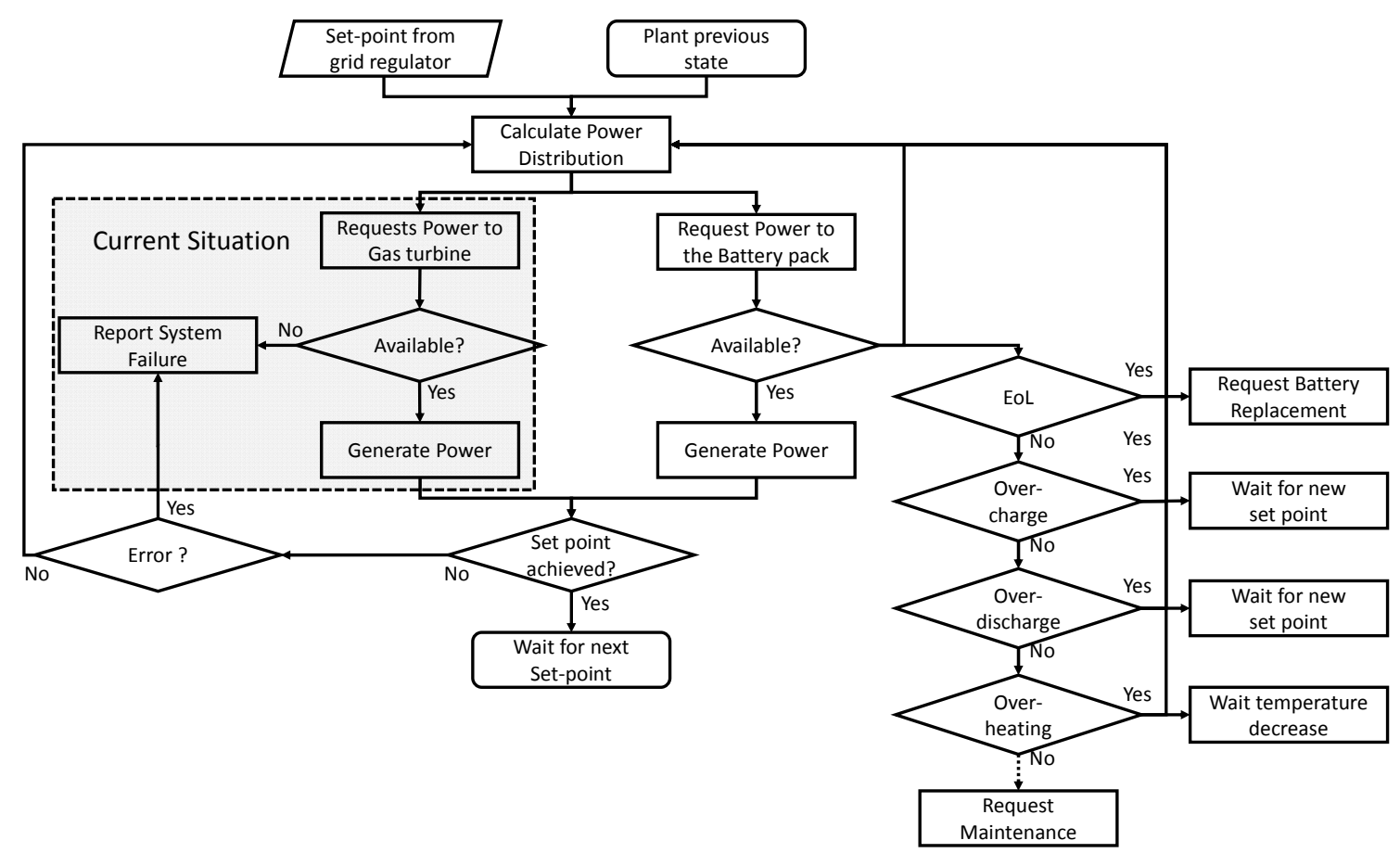

Figure 6. Simplified schema of the current control system of the power plant (grey) and its modification by the addition of the EV battery.

Additionally, this study assumes that there is only one reused EV battery to give support to the whole gas turbine system. Putting more batteries in series or parallel, thus multiplying their power and capacity, would significantly improve these aging results, as some of the aging factors would reduce their impact, such as $D o D, C$-rate, and Ah throughput. Howbeit, investments would increase in consequence, forcing a deep economic study to be performed.

Technically, batteries could participate directly in the area regulation market, absorbing or providing energy to the grid when needed. That is, there would be no baseline of energy to inject as it occurs now. Unfortunately, Spanish legislation does not allow batteries to participate in the area regulation market, so they need to work by the hand of another energy generation system.

Nonetheless, area regulation has a stronger tendency to increase the load demand rather than to decrease it, which is why the electricity grid presents the increase/decrease ratio as $58 \% / 42 \%$. This means that batteries would tend to be empty after some cycles and would need to recharge to be capable of running the system again. This is exactly the case of the presented hour timeframe, where the grid operator asks for higher amount of energy to inject to the grid, rather than to reduce it. Figure 7 presents how, between second 150 and 1550, the system is constantly injecting more energy than the baseline, and from there to second 3600 it stabilizes, finishing with an accumulated total 
energy of $101 \mathrm{kWh}$. In the presented situation, there is 123 accumulated $\mathrm{kWh}$ to increase and $22 \mathrm{kWh}$ to decrease during this $1 \mathrm{~h}$ period.

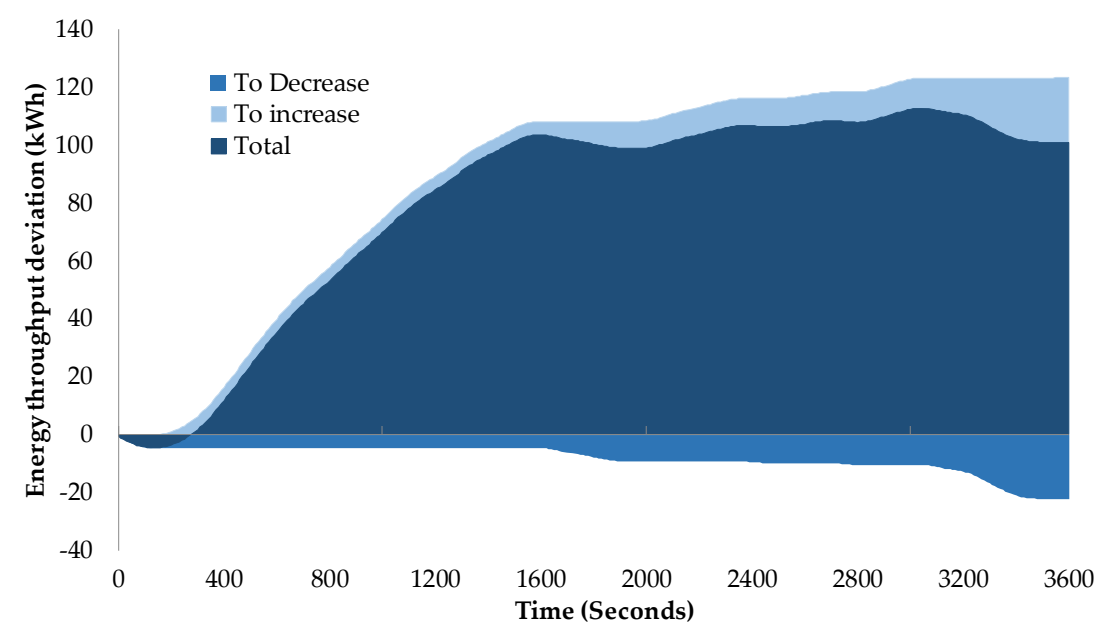

Figure 7. Energy deviation.

Moreover, the amount of batteries needed to provide $0.5 \mathrm{MW}$ power and the enormous quantity of energy derived represent a lot of batteries stacked together, needing deep economic business and cost analysis, which should be discussed in future works.

\section{Materials and Methods}

Generally, when a system enters into the area regulation market, the electricity grid operator examines it and fixes its maximum working load conditions and ramps up or down so the operator will not demand something that the facility cannot provide. In Spain, the market tendering fixes which system provides or reduces the energy to or from the grid $15 \mathrm{~min}$ prior to its incorporation, leaving little time for gas turbines to react. Each candidate offers a basic range of energy and a capability of $58 \%$ to increase and $42 \%$ to decrease it during $1 \mathrm{~h}$ periods, and the operator adapts the set points to the proposed bid.

This study bases its calculations on real demand area regulation data from the Spanish operator "Red Eléctrica" given to a gas turbine power plant. This power plant has several $50 \mathrm{~kW}$ gas turbines able to provide $0.5 \mathrm{MW}$ up/down. Figure 8 presents the set points that the plant should follow during $1 \mathrm{~h}$. Notice that these set points actualize every $4 \mathrm{~s}$, forcing the system to rapidly adapt to it.

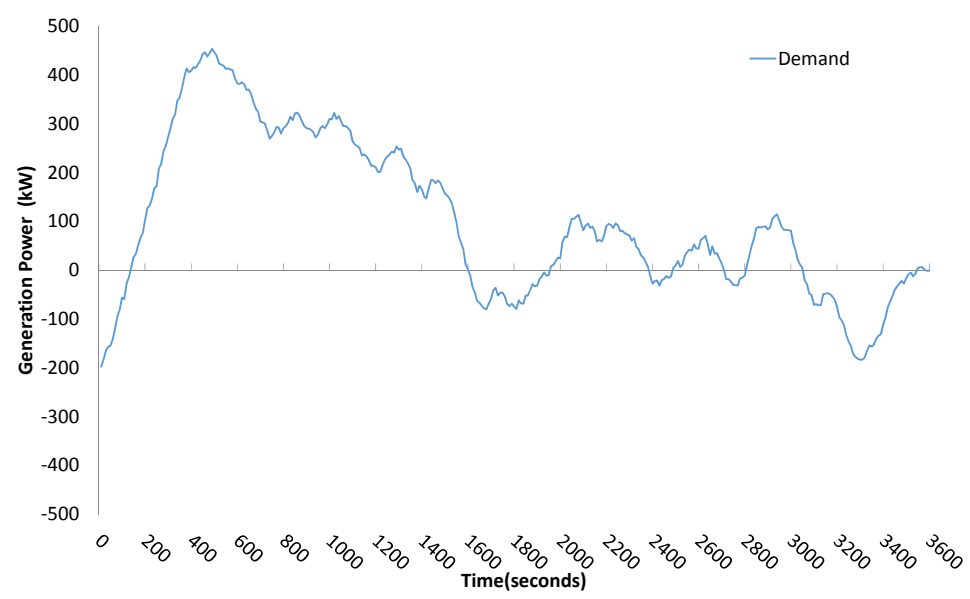

Figure 8. Set points fixed by the electricity grid operator that the generation plant should follow. 
Trying to upgrade this facility to a more competitive one, this study presents the possibility to improve the plant's time response and functionality by adding a second-life EV battery pack. This study presents two preliminary scenarios:

- Scenario 1: This scenario tries to minimize complications caused by fluctuations from the transitory states between set points [27]. This softening is achieved by transferring a recalculated working set point to turbines, based on the average power demand from the previous minute. In consequence, the response of turbines is softer and displaced $1 \mathrm{~min}$ while batteries provide or consume the lack or excess of energy. Figure 1 in the Results section presents the resulting load curves for turbines and battery.

- Scenario 2: Turbines work at constant speed or under constant acceleration/deceleration rates fixed at $2 / 3$ of the maximum capacity of the system, eliminating transitory inefficiencies and improving the turbine's lifespan by never working close to maximum acceleration rates. Similar to scenario 1, batteries provide or accumulate the necessary energy to adapt the turbine's electricity generation to the set point required by the grid operator. The maximum sustained power that the battery pack offers and accepts is $60 \mathrm{~kW}$. This value marks the maximum difference between the operator's set point and the working conditions of turbines. Thus, when the difference exceeds this limit, turbines will accelerate, stabilize, or reduce its velocity according to the previous working state. That is, if turbines were working at constant speed and the battery needs to provide more than $60 \mathrm{~kW}$, turbines will increase their power rate. On the other hand, if battery charge exceeds this limit, turbines will start to decrease their speed. Figure 2 in the Results section clarifies these explanations.

However, there are many aspects to take into account when repurposing an EV battery pack for second-life applications. In this study, we follow the direct reuse strategy, which means that the system uses the same battery pack of the vehicle, including the BMS. This strategy implies that there is no need to build a new BMS controlling different types or aged cells, as happens when following other strategies [28]. Moreover, as the use of one EV battery pack is enough to provide the power that the system demands, there is no need to develop an energy management system that balances power and capacity among multiple battery packs as reported by other studies [29,30]. Unfortunately, the direct reuse strategy needs to incorporate a gateway to communicate with the power system [31]. In addition, contrary to the example of a second-life battery pack developed for a smart grid-tied photovoltaic system that used a $48 \mathrm{~V}$ reassembled battery [32], the relatively high voltage of the reused EV battery pack of our study (which may reach up to $370 \mathrm{~V}$ ), and the power peak loads that raise above $50 \mathrm{~kW}$, force the development of specifically designed converters not available in the market at reasonable prices.

Concerning the delays in the system response, there are several aspects that ensure the correct or even better working operation of the system, even if the upgrade includes more elements in the communication's chain (see Figure 6 in Section 3 for more control details). As mentioned above, the grid regulator provides new set points every $4 \mathrm{~s}$. After the reception of the set point, the system calculates the power needed from the battery and turbines. Then, it sends the request to the converter and to the gas injectors. The converter activates the battery by increasing or decreasing the voltage and the battery responds much faster than the inertia from turbines to apply the power increase due to gas burn. Therefore, the introduction of battery storage systems does not increase the response delay, but instead provides a time buffer to correct the signal if any deviation is observed.

\subsection{Second-Life EV Battery Aging Model}

The second part of this study analyzes the second-life EV battery aging evolution under both scenarios. To do so, this study takes advantage of a previous work, which is a more accurate evolution from the model used in [33]. This aging model is based on an equivalent electric circuit that simulates the battery's behavior to calculate aging at every instant [21]. Typically, battery equivalent circuit 
models incorporate an ideal source that provides the open-circuit voltage (OCV in Figure 9) against SoC and a resistance in series with resistance and capacitator pairs (RC) in parallel. The resistance provides the instant voltage drop due to current load changes, while the first RC pair corresponds to fast voltage transitions. The use of simple models with a resistance and a single RC pair, such as the ones developed by Liaw et al. [34] or Cho et al. [35], is often chosen when fast calculations are needed. However, the addition of RC pairs, impedances, and Warburg impedances provide more accurate results [36,37].

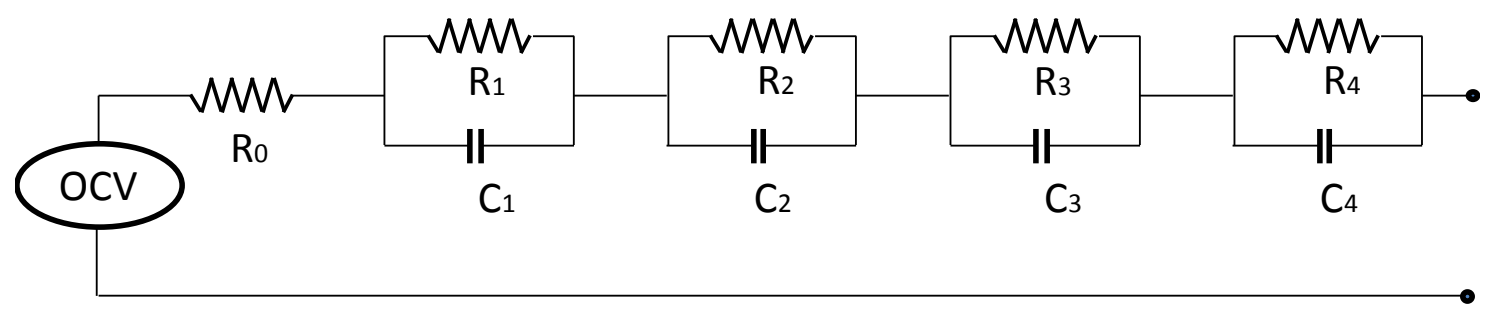

Figure 9. Schema of the electric equivalent model used [21].

Figure 9 shows the schema of the equivalent electric circuit model used in this study, which counts on a resistance (R) connected to four resistance and capacitator (RC) pairs. This model runs on Matlab ${ }^{\circledR}$ using Simulink ${ }^{\circledR}$ tools (MathWorks, Natick, NA, USA). The R and RC parameters were extracted from electrochemical impedance spectroscopy tests done at several temperatures between 0 and $55^{\circ} \mathrm{C}$. This aging model is based on nickel manganese cobalt (NMC)-chemistry prismatic cells. The capacity of the cells when fresh or new is $25 \mathrm{Ah}$, and they are used in commercial EV batteries. The whole battery pack uses 262 cells packed in modules forming two strings in parallel with a nominal voltage of $323 \mathrm{~V}$. To calculate the current going through a single cell, the battery power demand presented previously in Section 3 for each study case was divided by the OCV at each SoC, considering the whole battery. The resulting value was then divided by 2 , which corresponds to the number of parallel strings of modules in series. This approximation considers that all cells are identical and age similarly.

As presented in Figure 10, this aging model uses current and temperature as inputs to simulate the behavior of the battery along time. With the variation of current demand from and to the battery, SoC changes (Figure 4 ) and $D o D$ is extracted by rain-flow counting, obtaining all the parameters needed to estimate the capacity loss of the battery. The model takes into account calendar and cycling aging of batteries and most of the known factors affecting batteries' degradation. These factors are: temperature (T), depth of discharge $(D o D)$, state of charge (SoC), and current or intensity (C-rate) [38-40], which are incorporated in the aging model following Equations (1) and (2).

$$
\begin{gathered}
C_{\text {loss_cal }}=f(V, T, t) \\
C_{\text {loss_cyc }}=f(I, V, D o D, T, t)
\end{gathered}
$$

Calendar aging follows an Arrhenius-like curve related to voltage and temperature, which is defined by Equation (3).

$$
C_{\text {loss_cal }}=\left(\beta_{1}+\beta_{2} \cdot V\right) \cdot 10^{6} \cdot \mathrm{e}^{\frac{\beta_{3}}{T}} \cdot \sqrt{t}
$$

This model uses voltage to represent the aging effect of SoC, presented in Equations (1) and (2) and supported by literature [41,42]. In particular, its impact on cycling follows Equation (4):

$$
V_{\mathrm{ef}}=\theta_{4} \cdot V+\theta_{5}
$$


Regarding the cycling conditions, $D o D$ and C-rate affect battery aging following a logarithmic and second-degree polynomial expression, respectively [43,44], represented by Equations (5) and (6),

$$
\begin{gathered}
I_{\text {ef }}=\theta_{1} \cdot I^{2}+\theta_{2} \cdot I+\theta_{3} \\
D o D_{\text {ef }}=\frac{\log _{10}(D o D)}{2}
\end{gathered}
$$

Finally, the effect of temperature while cycling is related to the base-case degradation, according to Equation (7).

$$
T_{\text {ef }}=\frac{\mathrm{e}^{\frac{\theta_{6}}{T}}}{\mathrm{e}^{\frac{\theta_{6}}{298}}}
$$

In fact, Equations (3)-(7) represent the effect of these factors $(V, \mathrm{C}$-rate, $D o D$, and $T)$ against its base degradation, which is the capacity loss that occurs when cycling at $25{ }^{\circ} \mathrm{C}, 1 \mathrm{C}, 100 \% \mathrm{DoD}$, and $50 \%$ average SoC. Moreover, parameters $\beta_{1}, \beta_{2}, \beta_{3}, \theta_{1}, \theta_{2}, \theta_{3}, \theta_{4}, \theta_{5}$, and $\theta_{6}$, whose values are shown in Table 1 , are representative of one battery type.

Table 1. Values of the parameters in the model.

\begin{tabular}{ccccccccc}
\hline$\beta_{1}$ & $\beta_{2}$ & $\beta_{3}$ & $\theta_{1}$ & $\theta_{2}$ & $\theta_{3}$ & $\theta_{4}$ & $\theta_{5}$ & $\theta_{6}$ \\
\hline 21.75 & 7.543 & -6976 & 0.00001 & 0.0065 & 0.85 & 0.1667 & 0.9168 & -6976 \\
\hline
\end{tabular}

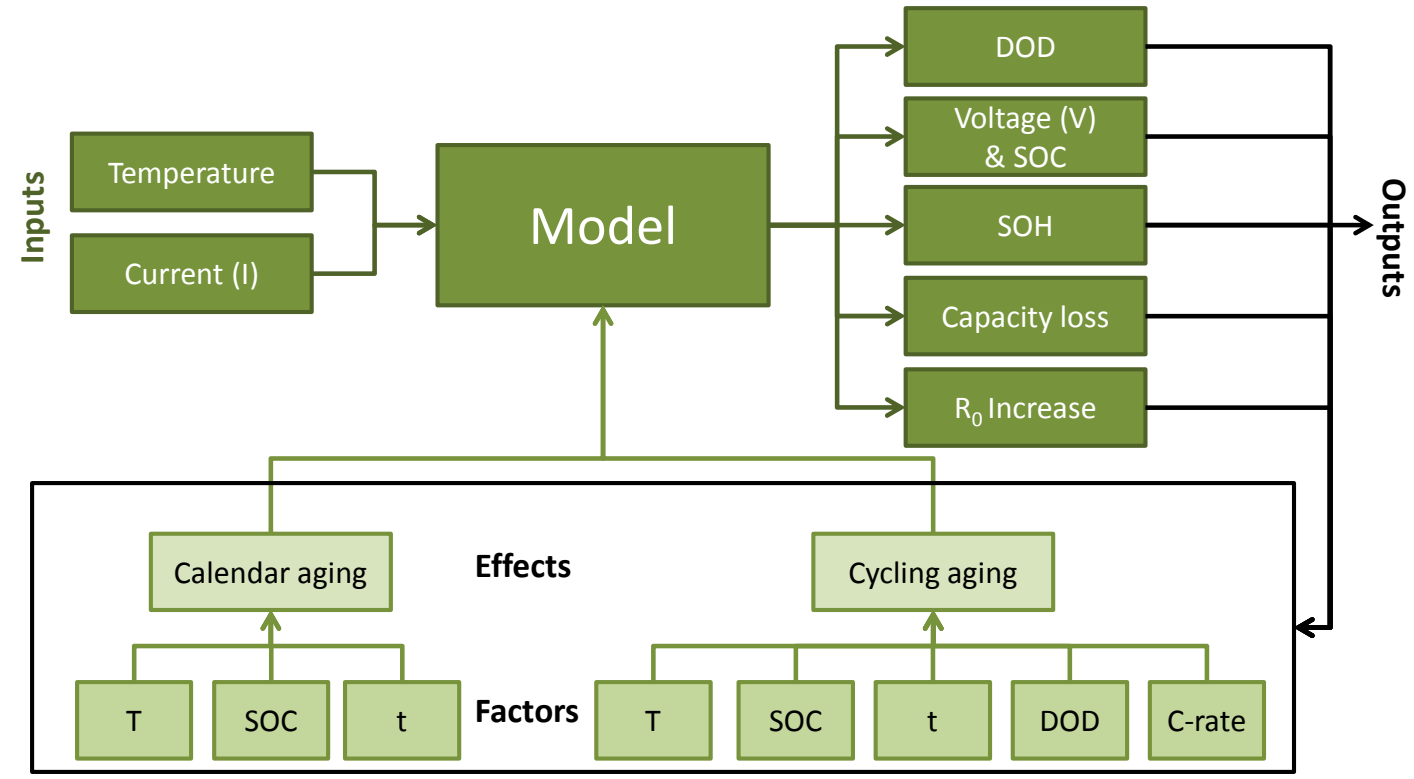

Figure 10. Schema of the aging model, identifying temperature and current as inputs, the factors affecting the calendar and cycling aging and the outputs of the model [24].

Then, SoH evolution, presented in Figures 3 and 5, is calculated by dividing the capacity of the battery at any instant by the initial capacity when fresh or new.

To ensure that no overvoltage occurs during the simulation, the model incorporates a condition that stops it when the battery voltage exceeds the working limits.

The last aspect to consider regarding the RUL estimation is that it is necessary to know the departing $\mathrm{SoH}$ of batteries. There are plenty of methods to estimate $\mathrm{SoH}$ of batteries, ranging from internal resistance and capacity measurements to fully automated onboard supervision of various battery parameters [45]. In this study, we expect to obtain SoH directly from the EV, as most EV models incorporate algorithms to estimate it. This study considers that second-life batteries will have an $80 \%$ 
$\mathrm{SoH}$, although there are some critical voices to this limit, as many drivers may continue using EVs well beyond it [46].

\subsection{Study Limitations}

This study presents a first battery lifespan estimation approach on area regulation considering all known aging factors. However, it has several limitations to notice.

First, it takes only a $1 \mathrm{~h}$ cycle to simulate the whole working conditions of the system along time. This is unlikely to happen, as area regulation changes constantly and the demand curve will never be the same. Nonetheless, it seemed a good assumption for an initial estimation. Future works will have to deal with this variability, where more than one battery will be certainly needed. Moreover, in this study, the system is assumed to be working $24 \mathrm{~h}$ a day, which is also difficult to occur, as it would mean that the system is always winning the auctions.

The turbine's upgrade scenarios may be improved by incorporating predictive tools and other factors that are closer to the problem in the reality of a turbine's regulation. However, it seemed inappropriate to use any, having only one representative curve, as they should be validated for several real cases. Therefore, we assumed that, in the scenarios presented, there was already an interest in batteries giving support to turbines on area regulation.

Finally, the aging model does not consider the "aging knee", a moment in which the aging mechanisms change and battery degradation may substantially accelerate [47].

\section{Conclusions}

This study presents the expected lifespan of second-life, directly reused, EV batteries giving power and energy support to gas turbine systems providing area and frequency regulation services under two working scenarios.

Batteries are responsible for absorbing the sudden changes from the electricity grid operator while smoothening the working conditions of gas turbines.

Results show that batteries age differently depending on the aggressiveness of the energy load. In fact, in the first scenario, which has lower battery requirements, the second-life EV battery works correctly for 1880 equivalent full cycles. On the other hand, more demanding load requirements, such as the one presented in the second scenario, lowers the battery lifespan down to 1241 equivalent full cycles, with the battery degradation accelerated by $21 \%$.

This paper also presents the relation between equivalent full cycles of the battery and working cycles, which shows that, for the analyzed scenarios, battery lifespan of the working cycles corresponds to 2000 and 800 cycles, respectively.

Finally, this study shows that, effectively, batteries may give support to area and frequency regulation services to gas turbines by improving the energy and electricity quality of the system.

Acknowledgments: The authors would like to thank the Universitat Politècnica de Catalunya (UPC) and the ReViBE project TEC2015-63899-C3-1-R (MINECO/FEDER) funded by the Spanish government.

Author Contributions: Beatriz Amante García prepared and obtained the raw data from Area Regulation and suggested system upgrades. Lluc Canals Casals prepared and ran the simulations. They both wrote the paper.

Conflicts of Interest: The authors declare no conflict of interest.

\section{References}

1. Denholm, P.; Jorgenson, J.; Jenkin, T.; Palchak, D.; Kirby, B.; Malley, M.O. The value of energy storage for grid applications. Contract 2013, 303. [CrossRef]

2. Eyer, J.; Corey, G. Energy Storage for the Electricity Grid: Benefits and Market Potential Assessment Guide: A Study for the DOE Energy Storage Systems Program; Sandia National Laboratories: Albuquerque, NM, USA, 2010.

3. Rastler, D. Electricity Energy Storage Technology Options; Electric power Research institute, Inc.: Palo Alto, CA, USA, 2010. 
4. Culver, W.J. High-value energy storage for the grid: A multi-dimensional look. Electr. J. 2010, 23, 59-71. [CrossRef]

5. El-Khattam, W.; Salama, M.M.A. Distributed generation technologies, definitions and benefits. Electr. Power Syst. Res. 2004, 71, 119-128. [CrossRef]

6. Güngör, V.C.; Sahin, D.; Kocak, T.; Ergüt, S.; Buccella, C.; Member, S.; Cecati, C.; Hancke, G.P. Smart grid technologies: Communication technologies and standards. IEEE Trans. Ind. Inform. 2011, 7, 529-539. [CrossRef]

7. Gitis, A.; Leuthold, M.; Sauer, D.U. Chapter 4-Applications and markets for grid-connected storage systems. In Electrochemical Energy Storage for Renewable Sources and Grid Balancing; Elsevier: Amsterdam, Netherlands, 2015; pp. 33-52.

8. Popper, K.; Hove, A. Energy Storage World Markets Report. Available online: https://www.eqmagpro. com/wp-content/uploads/2017/01/Energy_Storage_World_Markets_Report_2014-2020.compressed.pdf (accessed on 17 March 2017).

9. Dunn, B.; Kamath, H.; Tarascon, J.-M. Electrical energy storage for the grid: A battery of choices. Science 2011, 334, 928-935. [CrossRef] [PubMed]

10. Nykvist, B.; Nilsson, M. Rapidly falling costs of battery packs for electric vehicles-Pre publication Word version. Nat. Clim. Chang. 2015, 5, 329-332. [CrossRef]

11. Wolfs, P. An economic assessment of "second use" lithium-ion batteries for grid support. In Proceedings of the 2010 20th Australasian Universities Power Engineering Conference (AUPEC), Christchurch, New Zealand, 5-8 December 2010.

12. Foster, M.; Isely, P.; Standridge, C.R.; Hasan, M.M. Feasibility assessment of remanufacturing, repurposing, and recycling of end of vehicle application lithium-ion batteries. J. Ind. Eng. Manag. 2014, 7, 698-715. [CrossRef]

13. Neubauer, J.; Pesaran, A.; Williams, B.; Ferry, M.; Eyer, J. A Techno-economic analysis of PEV battery second use: Repurposed-battery selling price and commercial and industrial end-user value. In Proceedings of the SAE World Congress and Exhibition, Detroit, MI, USA, 24-26 April 2012.

14. Prüggler, W. The impact of second life applications of electric vehicle batteries on customer's mobility cost. In EnInnov 2012-12. Symposium Energieinnovation-Alternativen für die Energiezukunft Europas; Kurzfassungsband; Technishen Universität Graz: Graz, Germany, 2012.

15. Gohla-Neudecker, B.; Bowler, M.; Mohr, S. Battery 2nd life: Leveraging the sustainability potential of EVs and renewable energy grid integration. In Proceedings of the ICCEP 2015 5th International Conference on Clean Electrical Power: Renewable Energy Resources Impact, Taormina, Italy, 16-18 June 2015; pp. 311-318.

16. Cruz Gibert, H.; Cruz Zambrano, M.; Canals Casals, L.; Castella Daga, S.; Diaz Pinos, P. Sunbatt: Use of a second life battery system from PHEV in stationary applications. In Proceedings of the Smart City Expo World Congress, Barcelona, Spain, 17-19 November 2015.

17. Ramoni, M.O.; Zhang, H.C. End-of-life (EOL) issues and options for electric vehicle batteries. Clean Technol. Environ. Policy 2013, 15, 881-891. [CrossRef]

18. Neubauer, J.; Pesaran, A. The ability of battery second use strategies to impact plug-in electric vehicle prices and serve utility energy storage applications. J. Power Sources 2011, 196, 10351-10358. [CrossRef]

19. Viswanathan, V.V.; Kintner-Meyer, M. Second use of transportation batteries: Maximizing the value of batteries for transportation and grid services. IEEE Trans. Veh. Technol. 2011, 60, 2963-2970. [CrossRef]

20. Devie, A.; Dubarry, M. Durability and reliability of electric vehicle batteries under electric utility grid operations. Part 1: Cell-to-cell variations and preliminary testing. Batteries 2016, 2, 28. [CrossRef]

21. Canals Casals, L.; Amante García, B.; González Benítez, M.M. Aging Model for Re-used Electric Vehicle Batteries in Second Life Stationary Applications. In Project Management and Engineering Research. Lecture Notes in Management and Industrial Engineering; Ayuso Muñoz, J., Yagüe Blanco, J., Capuz-Rizo, S., Eds.; Springer: Cham, Switzerland, 2017; pp. 139-151.

22. Muenzel, V.; Hollenkamp, A.F.; Bhatt, A.I.; de Hoog, J.; Brazil, M.; Thomas, D.A.; Mareels, I. A comparative testing study of commercial 18650-format lithium-ion battery cells. J. Electrochem. Soc. 2015, 162, A1592-A1600. [CrossRef]

23. Canals Casals, L.; Amante García, B.; Castellà Dagà, S. The electric vehicle battery aging and how it is perceived by its drivers. Dyna 2016, 91, 188-195. [CrossRef] 
24. Ciccioni, P.; Landi, D.; Morbidoni, A.; Germani, M. Feasability analysis of second life applications for li-ion cells used in electric powertrain using environmental indicators. In Proceedings of the 2nd IEEE ENERGYCON Conference \& Exhibition, Sustainable Transportation Systems Symposium, Florence, Italy, 9-12 September 2012; pp. 985-990.

25. Strickland, D.; Chittock, L.; Stone, D.A.; Foster, M.P.; Price, B. Estimation of transportation battery second life for use in electricity grid systems. IEEE Trans. Sustain. Energy 2014, 5, 795-803. [CrossRef]

26. Muenzel, V.; De Hoog, J.; Brazil, M. A multi-factor battery cycle life prediction methodology for optimal battery management. In Proceedings of the 2015 ACM Sixth International Conference on Future Energy Systems, Bangalore, India, 14-17 July 2015; pp. 57-66.

27. Balamurugan, S.; Janarthanan, N.; Chandrakala, K.V. Small and large signal modeling of heavy duty gas turbine plant for load frequency control. Int. J. Electr. Power Energy Syst. 2016, 79, 84-88. [CrossRef]

28. Gladwin, D.T.; Gould, C.R.; Stone, D.A.; Foster, M.P. Viability of "second-life" use of electric and hybridelectric vehicle battery packs. In Proceedings of the IECON 2013 39th Annual Conference of the IEEE Industrial Electronics Society, Vienna, Austria, 10-13 November 2013; pp. 1922-1927.

29. Mukherjee, N.; Strickland, D. Control of second-life hybrid battery energy storage system based on modular boost-multilevel buck converter. IEEE Trans. Ind. Electron. 2015, 62, 1034-1046. [CrossRef]

30. Abdel-Monem, M.; Hegazy, O.; Omar, N.; Trad, K.; De Breucker, S.; Van Den Bossche, P.; Van Mierlo, J. Design and analysis of generic energy management strategy for controlling second-life battery systems in stationary applications. Energies 2016, 9, 889. [CrossRef]

31. Canals Casals, L.; Amane García, B. Communications concerns for reused electric vehicle batteries in smart grids. IEEE Commun. Mag. 2016, 54, 120-125. [CrossRef]

32. Tong, S.; Klein, M. Second life battery pack as stationary energy storage for smart grid. In Proceedings of the SAE 2014 World Congress \& Exihbition, Detroit, MI, USA, 8-10 April 2014.

33. Canals Casals, L.; Amante García, B.; Aguesse, F.; Iturrondobeitia, A. Second life of electric vehicle batteries: Relation between materials degradation and environmental impact. Int. J. Life Cycle Assess. 2017, 22, 82-93. [CrossRef]

34. Liaw, B.Y.; Jungst, R.G.; Nagasubramanian, G.; Case, H.L.; Doughty, D.H. Modeling capacity fade in lithium-ion cells. J. Power Sources 2005, 140, 157-161. [CrossRef]

35. Cho, S.; Jeong, H.; Han, C.; Jin, S.; Lim, J.H.; Oh, J. State-of-charge estimation for lithium-ion batteries under various operating conditions using an equivalent circuit model. Comput. Chem. Eng. 2012, 41, 1-9. [CrossRef]

36. Maciej, S.; Stroe, D.I.; Member, S.; Stan, A.; Teodorescu, R.; Sauer, D.U. Selection and performance-degradation modeling of $\mathrm{LiMO} / \mathrm{Li} \mathrm{Ti} \mathrm{O}$ and $\mathrm{LiFePO} / \mathrm{C}$ battery cells as suitable energy storage systems for grid integration with wind power plants: An example for the primary frequency regulation service. Trans. Sustain. Energy 2014, 5, 90-101.

37. Osaka, T.; Momma, T.; Mukoyama, D.; Nara, H. Proposal of novel equivalent circuit for electrochemical impedance analysis of commercially available lithium ion battery. J. Power Sources 2012, 205, 483-486. [CrossRef]

38. Vetter, J.; Nov, P.; Wagner, M.R.R.; Veit, C.; Novák, P.; Möller, K.-C.; Besenhard, J.O.; Winter, M.; Wohlfahrt-Mehrens, M.; Vogler, C.; et al. Aging mechanisms in lithium-ion batteries. J. Power Sources 2005, 147, 269-281. [CrossRef]

39. Eddahech, A. Modelisation du Vieillissement et Determination de L'etat de Sante de Batteries Lithium-Ion Pour Application Vehicule Electrique et Hybride; Université Sciences et Technologies: Bordeaux, France, 2013. (In French)

40. Warnecke, A. Ageing effects of lithium-ion batteries. In Proceedings of the 17th Conference on Power Electronics and Applications, Geneva, Switzerland, 8-10 September 2015; pp. 1-20.

41. Schmalstieg, J.; Käbitz, S.; Ecker, M.; Sauer, D.U. A holistic aging model for Li(NiMnCo)O $\mathrm{O}_{2}$ based 18650 lithium-ion batteries. J. Power Sources 2014, 257, 325-334. [CrossRef]

42. Delaille, A.; Grolleau, S.; Duclaud, F. SIMCAL Project: Calendar aging results obtained on a panel of 6 commercial Li-ion cells. In Electrochemical Energy Summit; Electrochemical Society: San Francisco, CA, USA, 2013; Volume 101.

43. Guena, T.; Leblanc, P. How depth of discharge affects the cycle life of lithium-metal-polymer batteries. In Proceedings of the 28th Annual International 2006 Telecommunications Energy Conference, Gold Coast, Australia, 22-26 October 2006; pp. 1-8. 
44. Sarasketa-Zabala, E.; Laresgoiti, I.; Alava, I.; Rivas, M.; Villarreal, I.; Blanco, F. Validation of the methodology for lithium-ion batteries lifetime prognosis. In Proceedings of the EVS27 Electric Vehicle Symposium, Barcelona, Spain, 17-20 November 2013; pp. 1-12.

45. Goebel, K.; Saha, B.; Saxena, A.; Celaya, J.R.; Christophersen, J.P. Prognostics in battery health Management. IEEE Instrum. Meas. Mag. 2008, 11, 33-40. [CrossRef]

46. Saxena, S.; Le Floch, C.; Macdonald, J.; Moura, S. Quantifying EV battery end-of-life through analysis of travel needs with vehicle powertrain models. J. Power Sources 2015, 282, 265-276. [CrossRef]

47. Martinez-Laserna, E.; Sarasketa-Zabala, E.; Stroe, D.; Swierczynski, M.; Warnecke, A.; Timmermans, J.M.; Goutam, S.; Rodriguez, P. Evaluation of lithium-ion battery second life performance and degradation. In Proceedings of the IEEE Energy Conversion Congress and Expo, Milwakee, WI, USA, 18-22 September 2016.

(C) 2017 by the authors. Licensee MDPI, Basel, Switzerland. This article is an open access article distributed under the terms and conditions of the Creative Commons Attribution (CC BY) license (http:/ / creativecommons.org/licenses/by/4.0/). 